\title{
Bunia Swahili and Emblematic Language Use
}

\author{
Nico Nassenstein \\ Johannes Gutenberg-Universität Mainz \\ nnassens@uni-mainz.de \\ GerritJ. Dimmendaal \\ Universität zu Köln \\ gerrit.dimmendaal@uni-koeln.de
}

\begin{abstract}
The present paper provides first insights into emblematic language use in Bunia Swahili, a variety of the Bantu language Swahili as spoken in and around the city of Bunia in Ituri Province, Democratic Republic of the Congo. Structural variability in Bunia Swahili shows that this language variety consists of basilectal, mesolectal and acrolectal registers, which are used by speakers to express different social identities. Whereas the basilectal variety shows structural similarities with Central Sudanic languages, the mesolectal and acrolectal registers are closer to East Coast Swahili. We argue that these lectal forms are to be understood as fluid repertoires which are used by speakers as a form of adaption to different conversational settings and as indexical representations of their (ethnic) identity. We go on to describe the historical background to these diverging ways of speaking Bunia Swahili, which are due mainly to the long-lasting conflict between different groups in the area.
\end{abstract}

\section{Keywords}

Swahili - emblematicity - language contact - replication - lectal variation pidginization

Swahili, a lingua franca with up to 100 million speakers in East and Central Africa, is best known from descriptions of Standard Swahili, which is used as an

(C) NICO NASSENSTEIN AND GERRIT J. DIMMENDAAL, 2020 | DOI:10.1163/19552629-01203008

This is an open access article distributed under the terms of the prevailing CC-BY-NC License at the time of publication. 
official language in Kenya and Tanzania and which is based on Coastal Swahili, more specifically the dialect of Zanzibar, hereafter abbreviated as Ecs; see, for example, Ashton (1944), Polomé (1967) and Mpiranya (2015) for detailed descriptions. Nurse and Hinnebusch (1993), who give a detailed historical account of the origin and spreading of this lingua franca, argue that Swahili gradually spread as a lingua franca along the East African coast from the $9^{\text {th }}$ century AD onwards. Möhlig and Miehe (1995) present a collection of studies on Swahili dialects (mainly those spoken along the East African coast). Additional varieties include "up country Swahili" (or Kisetla), which emerged in the Kenyan Highlands between European settlers and Kenyans. More recently, urban varieties such as Sheng in Kenya and Lugha ya Mitaani in Tanzania emerged; the interested reader is referred to Nassenstein and Hollington (2015) as well as Reuster-Jahn and Kießling (2006) for further details.

During the $19^{\text {th }}$ century, Swahili also spread inland as far as what is now the Democratic Republic of Congo (hereafter DRC), as discussed in more detail below. These geographically peripheral Central African varieties are dialects associated with major cities in DRC, such as Lubumbashi, Bukavu, Goma, and Bunia.

Bunia Swahili, also known as Ituri Kingwana, has been claimed to be a "pidginized" or "creolized" variety of Standard Swahili. For example, Harries (1955) and Heine (1973: 6o) classify it as a pidginized form of Swahili, while Vorbichler (1979) describes it as a simplified, mutated form of the language. In her paper on the secret language Lungunya, which is based on Bunia Swahili, Kutsch Lojenga (2009) categorizes Bunia Swahili as a creolized variety of Swahili. The common designation of Bunia Swahili as 'Kingwana' (from wangwana as "civilized people" in opposition to washenzi "savages") was first initiated by missionaries, based on their derogatory attitude towards this variety of Swahili, which was associated with less prestigious or less elaborated forms of this East African contact language (see also Fabian 1986 for a discussion).

As shown hereafter, Bunia Swahili in fact consists of several lects or registers which emerged in a multilingual "arena", whereby only the basilectal variety deviates considerably from Swahili as spoken elsewhere in the D RC, or Swahili as spoken in Tanzania and Kenya for that matter. Whereas superficially this variety may look like pidginized or creolized Swahili, we will argue that it is the result of replication from local Central Sudanic languages.

Speakers nowadays designate basilectal varieties of Bunia Swahili as 'deep Kingwana' or 'Kingwana profond', in opposition to acrolectal registers which would simply be labeled 'Bunia Swahili', 'Congo Swahili' or 'Swahili'. Below, we first describe the spreading of Swahili as an erstwhile coastal language into the 
interior (Section 2), before embarking upon an account of variation within $\mathrm{Bu}-$ nia Swahili itself.

\section{Sociolinguistic Background to the Present Study}

Speakers from Ituri Province, DRC are usually multilingual and their linguistic resources are diverse. Many individuals speak a regional variety of Swahili (whereby the prefix $k i$ - is used to denote the language in general) known as $\mathrm{Bu}$ nia Swahili, which serves as a lingua franca alongside other regional languages, including Kihema, Lendu and Ngiti. French is the official language of the country, while Lingala serves as the predominant language of power because of its use in the Congolese army and police. Kivu Swahili, named after a variety spoken in another urban center in Eastern Congo, also serves as a prestigious local lingua franca.

The north-eastern corner of the DRC is characterized by a considerable degree of linguistic diversity. Apart from Bantu (i.e. Niger-Congo) languages such as Kibila and Kihema, there are Central Sudanic (i.e. Nilo-Saharan) languages such as Lendu and Ngiti as well as Nilotic (i.e. Nilo-Saharan) languages such as Alur and Kakwa.

Fahey (2013:14-15), in his detailed study on politics in the Ituri region of the DRC, estimates the Lendu migration to Ituri to have occurred during the $16^{\text {th }}$ century from areas that are today part of South Sudan. While some Lendu (also known as Bbale) settled in northern parts of Ituri (today's Mahagi and Djugu Territories), others (known as Ngiti) settled further south. Pastoral Hema groups, i.e. speakers of a Bantu language probably originating from the Bunyoro Kingdom (nowadays Uganda), began to populate the area only in the $18^{\text {th }}$ century, according to oral traditions (see Fahey 2013). Those settling west of Lake Albert came to be known as the Bagegere, or Northern Hema, and shifted to a variety of Lendu known as Jidha (or Kigegere) as their first language. According to Fahey (2013), Northern Hema people began to establish political and economic dominance over the Lendu, practiced intermarriage with Lendu women and adopted agricultural practices from them. The Southern Hema settled southwest of Lake Albert, but kept their Bantu language Kihema, and established dominance over the Ngiti. Instead of adopting agricultural practices from the Ngiti, the latter adopted cattle herding from the Southern Hema.

These developments depict the blurry and cross-ethnic hybridization of language solidarity and changes in cultural practices, and also illustrate how 
complex a categorization of 'being Hema' or 'being Lendu' has become as a result of ethnogenesis, more specifically ethnic fission and fusion. Despite their adoption of the Lendu language, Northern Hema (Bagegere) feel close historical bonds with Southern Hema, whereas Lendu feel closely affiliated with Ngiti (among whom numerous have become cattle herders, rather than being agriculturalists like most Lendu people). These emblematic alliances became particularly evident during the 'Ituri War' (1999-2003), which intensified ethnic ascriptions of differentiation, and turned 'Hema identity' versus 'Lendu/Ngiti identity' into political labels (see also Pottier, 2009, for the historical roots of the political conflict) - and likewise their languages became political emblems.

While Goyvaerts \& Kabemba (1986: 212-213) suggest three possible scenarios for the spreading of Swahili into the Congo basin from approximately 1830 onwards (north of Lake Tanganyika, across the lake, or through Katanga in the southeast), the Katanga passage is seen as the most common explanation. This entry point (and point of diffusion) of Swahili is often associated with major figures in the history of Congo, such as Tippu Tip and Msiri (see Fabian, 1986: 6-9). However, as argued below (Section 4.2), this explanation is not fully satisfactory in order to explain Bunia Swahili, for example when tracing back its morphological features.

Within today's D RC, the following Swahili dialects can be identified: Lubumbashi Swahili/Katanga Swahili (also labeled as Copperbelt/Shaba Swahili),

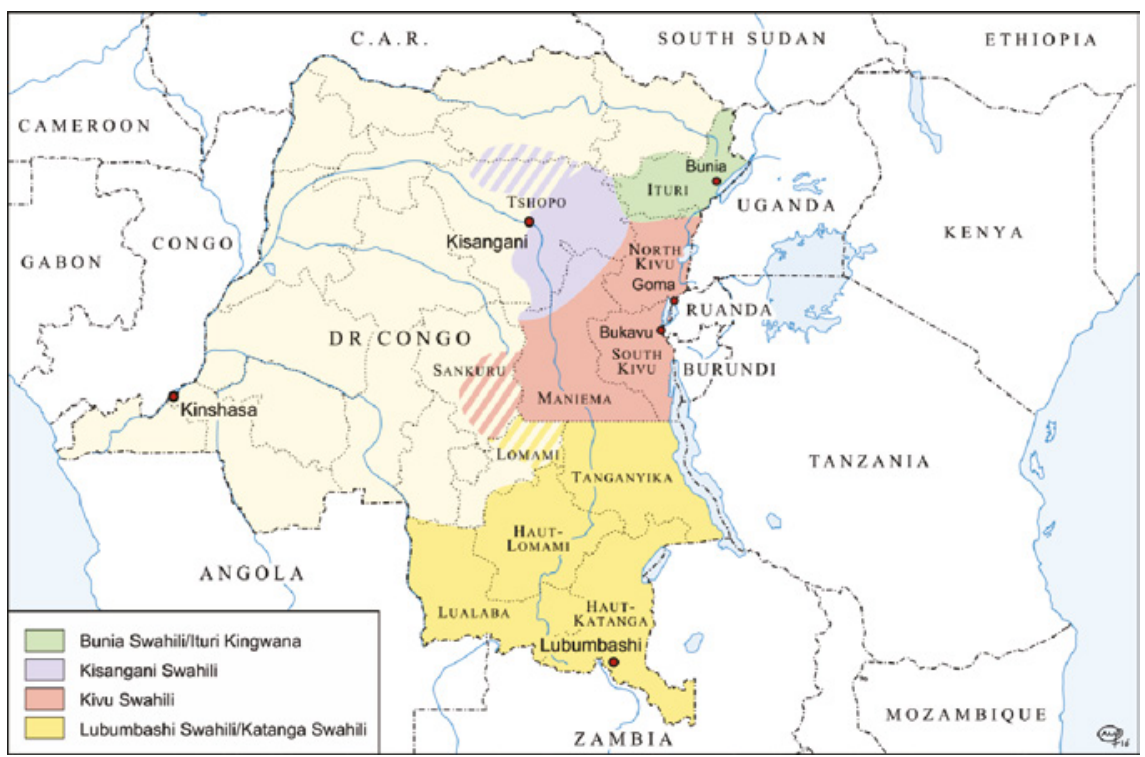


Kivu Swahili (also referred to as Goma/Bukavu Swahili or Kingwana), Kisangani Swahili (sometimes also subsumed under the label of Kingwana), and Bunia Swahili (also known as Ituri Kingwana); see Nassenstein $(2015,2017)$ and Nassenstein \& Bose (2016) for a preliminary discussion. The latter variety appears to have gone largely unnoticed in earlier surveys of Swahili dialects; authors like Möhlig (1995) and Maho (2009), for example, do not mention Bunia Swahili.

Most speakers of Bunia Swahili are highly multilingual individuals who use several languages in their social interactions on a daily basis, and often acquire languages like Lendu or Hema as their primary language in the family context. As with other languages in the area, the use of a specific register of Bunia Swahili can express speakers' ideologies and intersubjective attunement towards the conversational partner(s). In fact, a speaker of Bunia Swahili can in most cases shift (to a certain extent) from one register to another, each register evoking specific associations and emotions and being representative of a linguistically performed social identity. The phonological and morphosyntactic details of these registers are illustrated first.

\section{Variation within Bunia Swahili}

Language use in Bunia is best understood as a set of repertoires whereby the use of basilectal, mesolectal or acrolectal registers of Bunia Swahili depend upon the representations of one's social identity as expressed, concealed, or negotiated through the use of a specific 'way of speaking'.

The basilectal realization manifests a strong influence from local Central Sudanic languages and differs from the mesolectal and acrolectal realizations in terms of both phonology and morphosyntax. The acrolectal register is both morphosyntactically and lexically more oriented towards (East African) Coastal Swahili. Most speakers are capable of adapting their register of Bunia Swahili to the situated context, depending on their educational, social or religious background. This has to do with speakers' social needs and strategies of 'Selfing' and 'Othering'. Consequently, this variation in the use of registers can be best described in terms of a "sliding scale" (as when one pushes a slider to change the volume of music, to dim the light, etc.), reflecting the tacit knowledge speakers have of the implied sociological parameters when changing their way of speaking Bunia Swahili.

In order to determine potential 'ethnic registers' of speakers, methods of 'linguistic profiling' were used during fieldwork sessions for the present contribution. Speakers of Southern Hema, Northern Hema and Lendu origin were exposed to audio data collected through radio broadcasts (from Radio Canal Révélation), which depicted a more 'basilectal register'. They would describe 


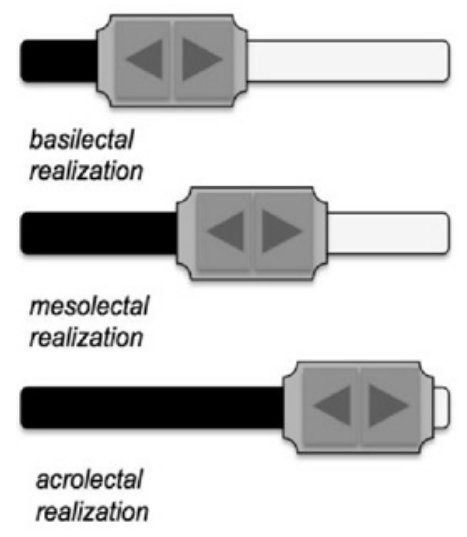

FIGURE 1

Slider model of Bunia Swahili speakers' variability

this specific variety as a 'Lendu way of speaking' (also due to recurrent lexical borrowings from Lendu), whereas a conversation between two speakers in a more 'acrolectal register' (clearly oriented at Ecs lexicon and morphosyntax) was classified by the same speakers as a 'Hema way of speaking'. They would also claim that the chosen ('basilectal') audio samples from the radio broadcast, containing words such as bombors 'beer, brew' and striking phonological features described as "l'intonation du deep Kingwana" ('the intonation of 'deep Kingwana' as uttered by a Congolese in Kampala), were expressions of emblematic Lendu identity.

There is also a set of structural features characteristic of Bunia Swahili as such, regardless of the specific register used by speakers. This set includes the way basic sentence structure is organized, the way specific syntactic categories like adjectives are conjugated, the system of pronominal cross-reference marking, and the use of certain other grammatical characteristics. Before embarking upon these more general structural properties, we first discuss lectal variation within Bunia Swahili.

\subsection{Phonological Variation}

The consonant inventory of Bunia Swahili is largely identical to that of other western varieties of Swahili as well as Standard Swahili; see Nassenstein (2015: 29) for an inventory of the western variety Kisangani Swahili, and Polomé (1967: 38-39) for a summary of consonants in ECs. The following table summarizes the set of contrastive consonant units in acrolectal Bunia Swahili (with corresponding orthographic representations rendered as $<>$, whenever we use these instead of the IPA symbols), followed by a discussion of variation with regard to other local varieties.

In line with phonotactic conditions in the Central Sudanic languages Lendu and Ngiti, clusters of non-homorganic nasal plus obstruent, as found in ECS, 
TABLE 1 The phoneme inventory of acrolectal Bunia Swahili

bilabial labio-dent. alveolar post-alveolar palatal velar glottal

\begin{tabular}{|c|c|c|c|c|c|c|}
\hline Nasal & $\mathrm{m}$ & & $\mathrm{n}$ & & n $<$ ny $>$ & $\mathrm{y}<\mathrm{ng}^{\prime}>$ \\
\hline \multirow[t]{2}{*}{ Stop } & $\mathrm{p} b$ & & $\mathrm{t} d$ & & $\mathrm{j}<\mathrm{j}>$ & $\mathrm{k}$ \\
\hline & & & & & & g \\
\hline Fricative & & $\mathrm{f} v$ & $\mathrm{~S} \quad \mathrm{z}$ & $\int<\operatorname{sh}>$ & & $\mathrm{\gamma}<\mathrm{gh}>$ \\
\hline Approximant & $\mathrm{w}$ & & & & $\mathrm{j}<\mathrm{y}>$ & $\mathrm{h}$ \\
\hline Tap/Flap & & & $\mathrm{r}<\mathrm{r}>$ & & & \\
\hline Lat. Approx. & & & l & & & \\
\hline Affricate & & & & $\mathrm{t} \int<\mathrm{ch}>$ & & \\
\hline Prenasalized & $\mathrm{mb}$ & $\mathrm{mv}$ & nd & & $n j<n j>$ & ng \\
\hline
\end{tabular}

are avoided in Bunia Swahili by inserting a vowel between the two; thus, $k u$ pumzika 'to relax' changes to kupumuzika.

Another common feature in Bunia Swahili is the elision of stem-initial vowels before a nasal-consonant cluster, as found in ECs verb stems like -andika 'write', -anguka 'to fall' and -ingia 'to enter', which are realized as -ndika, -nguka, -ngiya. While all Swahili words that contain ' $r$ ' are realized with an alveolar tap [r], the ' $r$ '-sound in French loan words is realized as a uvular trill [R]. Certain speakers, in particular those who have been in contact with Kisangani Swahili (or Lingala, which only has the uvular trill in French loanwords), may treat these as free variants in Bunia Swahili. The voiced velar fricative [y] only occurs in unadapted lexical borrowings from Arabic into Coastal Swahili, and is used by speakers who intend to speak closer to this standard variety. Hence, they would say [luya] for 'language', instead of [luga] or [luka], which are the more commonly used forms in the Bunia area.

The phonology of the mesolectal variety is marginally different from that of the acrolectal variety, for example in that the ECS approximant $h$ is absent. Word-initially, this approximant is produced by acrolectal speakers as an emblematic sound associated with Standard Swahili, as in hadithi 'story', which is pronounced as adisi by all other speakers. The mesolectal register differs from the basilectal and the acrolectal forms mainly in terms of its morphosyntactic structure, as further discussed below.

The acrolectal variety of Bunia Swahili has five vowel phonemes, as in Standard Swahili (spoken in Tanzania or Kenya). These are realized as nine vowels at the phonetic level, again as in Standard Swahili (see Polomé, 1967:46-47 for a description). 
TABLE 2 The vowel inventory of acrolectal Bunia Swahili

\begin{tabular}{|c|c|c|c|}
\hline \multirow[t]{2}{*}{ front close } & {$[\mathrm{i}]$} & kulia & 'to cry' \\
\hline & & kiyana & 'masculinity, youth' \\
\hline \multirow[t]{2}{*}{ front close-mid } & {$[\mathrm{e}]$} & kujenga & 'to build' \\
\hline & & nywele & 'hair' \\
\hline front open-mid & {$[\varepsilon]$} & kubsba & 'to carry' \\
\hline \multirow{2}{*}{ front open } & {$[\mathrm{a}]$} & mafuta & ‘oil’' \\
\hline & & kutafuta & 'to look for' \\
\hline \multirow[t]{2}{*}{ back close } & {$[\mathrm{u}]$} & kufunga & 'to close' \\
\hline & & mutu & 'person' \\
\hline \multirow[t]{2}{*}{ back close-mid } & {$[\mathrm{o}]$} & soko & 'market' \\
\hline & & mukono & 'hand/s' \\
\hline \multirow[t]{2}{*}{ back open-mid } & {$[\supset]$} & kukolspa & 'to sweep' \\
\hline & & nyska & 'snake’ \\
\hline
\end{tabular}

However, in the basilectal variety of Bunia Swahili, these nine vowels have received phonemic status, in that vowels within a word all tend to belong to one of two harmony sets consisting either of a set of [-Advanced Tongue Root] $([-\mathrm{ATR}])$ vowels, I, $\varepsilon, \mathrm{a}, \mathrm{o}$, and $\mathrm{v}$, or a set of [+Advanced Tongue Root] ([+ATR $]$ ) vowels, i, e, o, and u. ${ }^{1} \mathrm{~A}$ comparison of the acrolectal and the basilectal pronunciation of words shows that these harmonic conditions in the basilectal variety are fulfilled by extending the $[-\mathrm{ATR}]$ or [+ATR] quality of vowels to neighboring vowels in the same word.

This system parallels ATR-harmony conditions as found in Central Sudanic languages like Lendu or Ngiti (Kutsch Lojenga, 1994), where vowels within a word also tend to belong to one of the two harmony sets, namely a [-ATR] set consisting of $\mathrm{I}, \varepsilon, \mathrm{a}, \mathrm{o}$, and $\mho$, and a [+ATR] set consisting of i, e, o, and u. Kutsch Lojenga

\section{Acrolectal variant Basilectal variant}

\begin{tabular}{|c|c|c|c|}
\hline mimi & [mr'mi] & {$[\mathrm{mImI}]$} & 'I’ \\
\hline yote & {$\left[j \jmath^{\prime}\right.$ te $]$} & {$[j \mathrm{j} t \varepsilon]$} & 'all' \\
\hline mutu & {$\left[\mathrm{m}_{1} \mathrm{v}^{\prime} \mathrm{tu}\right]$} & [mutu] & 'person' \\
\hline yetu & {$\left[\mathrm{j} \varepsilon^{\prime} \mathrm{tu}\right]$} & {$[$ jetu $]$} & ‘our' \\
\hline
\end{tabular}

1 Following a common tradition in the study of African languages with ATR harmony, vowel symbols as presented in Table 2 are used in the present study, rather than the actual IPA symbols. Hence, $[-\mathrm{ATR}]$ ह is written as $<\varepsilon>$ and e is written as $<\mathrm{e}>$, i.e. without the corresponding diacritics. It should be noted, however, that in ECS the production of these vowels involves manipulation of the lips and tongue blade, but not of the tongue root. 


\begin{tabular}{|c|c|c|c|c|c|}
\hline & & & [-back] & [+back] & \\
\hline & & & \multicolumn{2}{|l|}{ [-round] } & [+round] \\
\hline \multirow[t]{3}{*}{ [+high] } & {$[-$ low $]$} & [+ATR $]$ & $\mathrm{i}$ & & $\mathrm{u}$ \\
\hline & & {$[-\mathrm{ATR}]$} & $\dot{\mathbf{i}}$ & & u \\
\hline & & [+ATR $]$ & e & & o \\
\hline \multirow[t]{2}{*}{ [-high] } & & {$[-\mathrm{ATR}]$} & $\varepsilon$ & & o \\
\hline & [+low] & [-ATR $]$ & & $\mathrm{a}$ & \\
\hline
\end{tabular}

TABLE 4 Harmony sets in Ngiti

\begin{tabular}{|c|c|c|c|}
\hline [+ATR $]$ & & {$[-\mathrm{ATR}]$} & \\
\hline $\begin{array}{l}\text { itsu } \\
\text { mùnovhi }\end{array}$ & $\begin{array}{l}\text { 'tree' } \\
\text { 'soldier' }\end{array}$ & $\begin{array}{l}\grave{t} b h \dot{\varepsilon} \\
\text { mòhsndì }\end{array}$ & $\begin{array}{l}\text { 'fish' } \\
\text { 'wedding feast' }\end{array}$ \\
\hline
\end{tabular}

(1994: 55) gives the vowel inventory listed in Tables (3-4) for Ngiti (whereby $\dot{i}$ represents [-ATR] I and $u$ represents [-ATR ] 0 ). The Ngiti examples from Kutsch Lojenga (1994:63) illustrate these structural conditions within a word.

This basilectal variety of Bunia Swahili shares another striking feature with the Central Sudanic languages Lendu and Ngiti, namely frequency or pitch (i.e. tone), rather than amplitude (stress), as a prosodic feature. In Standard Swahili, the penultimate vowel of the word carries stress and is slightly lengthened, as in example (1). Lendu and Ngiti distinguish between a low tone (marked as '), a mid tone (left unmarked in the examples quoted from these languages in the present contribution) and a high tone (marked as ') on vowels as well as on the consonants $\mathrm{s}, \mathrm{z}$ and $\mathrm{r}$; there is no distinctive vowel length in these two Central Sudanic languages. In the basilectal variety of Bunia Swahili, penultimate lengthening of vowels (as a feature accompanying stress) is omitted entirely, and all vowels are pronounced with roughly the same length. Moreover, these vowels receive a distinct tone. The following example from a recorded conversation illustrates the prosodic and grammatical structure of the basilectal form of Bunia Swahili (3a) and the corresponding realization of the same sentence in Standard Swahili ( $3 b$ ) for comparison. Note that tone and vowel quality are only marked in the basilectal examples (3a and 5), while elsewhere the representation follows the orthographic conventions of Standard Swahili. 


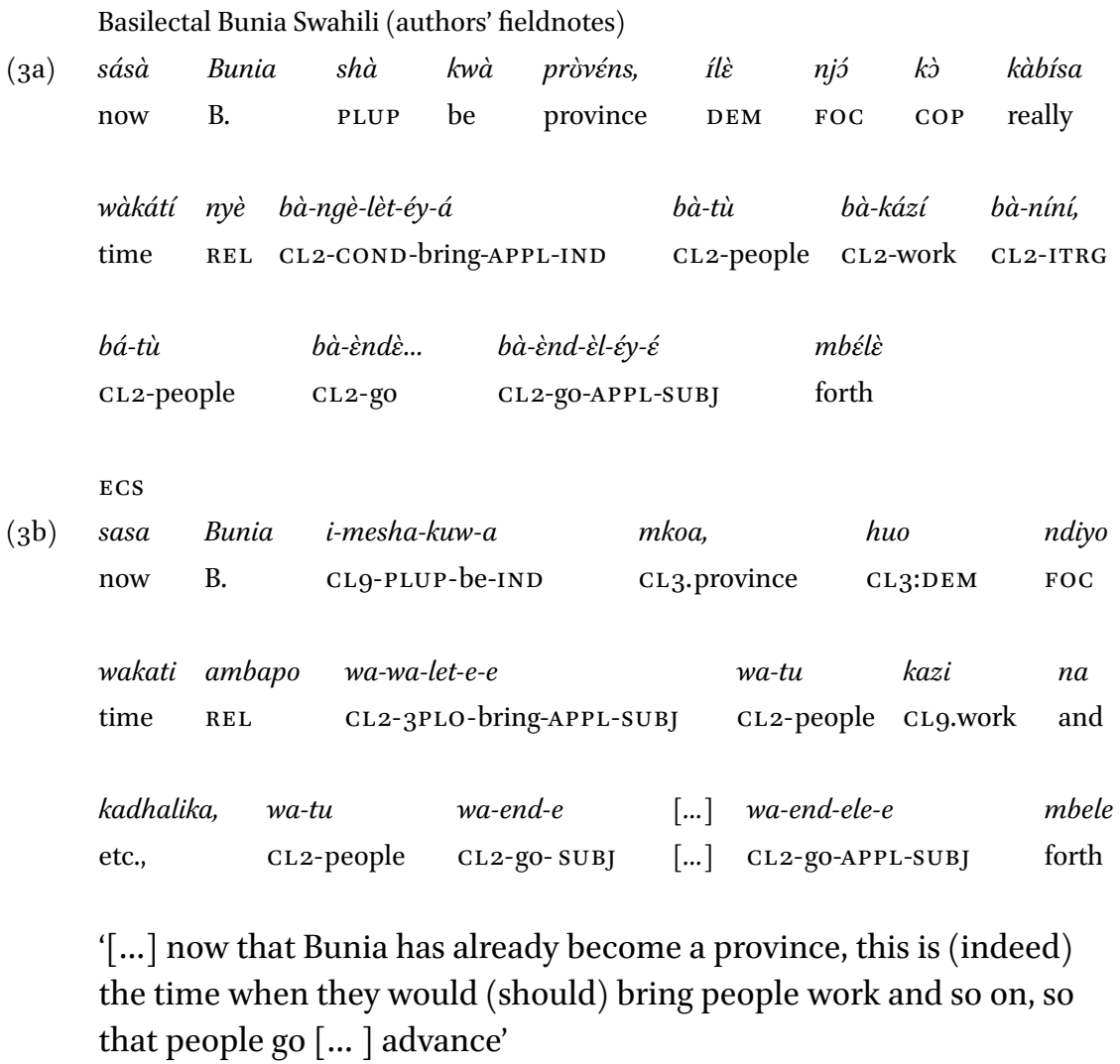

The absence of sequences of identical vowels in all varieties of Bunia Swahili is a feature shared with other Congo (i.e. Western) Swahili varieties. In Standard Swahili, these are mostly found in borrowings from Arabic (saa 'hour, time') but also in words of Bantu origin (kukaa 'to live, inhabit'). In Bunia Swahili, such sequences are split into two syllables through the epenthesis of a glottal approximant $h$ or a lateral approximant $l$; hence, saa becomes saha (see example 4), and taa becomes tala. This is also the case for other Congo Swahili varieties (Kapanga, 1993). An example from mesolectal Bunia Swahili:
(4) We-ta-fik-a
saha
kaní?
2SG-FUT-arrive-IND
cLg.hour
ITRG
'When are you going to come back?' 
Diphthongs, which are found in ECs verb stems like -sahau 'forget', also tend to be split in Bunia Swahili (all registers) by inserting voiced stops, changing it to -sahabu. This again occurs in other Congo Swahili varieties. Omission of the glide $w$ after another consonant in syllable onsets is a further example where variation between speakers can be observed. Thus, Standard Swahili nywele 'hair' becomes nyele and -nywa 'to drink' becomes -nya in the mesolectal and basilectal registers (but not necessarily the acrolectal variety). Whereas in Central Sudanic languages belonging to the Moru-Madi cluster labialized consonants are common, Lendu and Ngiti also avoid such clusters. This may be interpreted as a further example of the syllabic and prosodic adaptation of non-acrolectal Bunia Swahili registers to other languages in the area. The following example from a conversation between two speakers of the basilectal variety of Bunia Swahili is a further illustration of the presence of tone as a prosodic feature in this variety.

Basilectal Bunia Swahili

$\begin{array}{lllllll}\text { Jé } & \text { básì } & \text { mà-sóló } & y a ̀ & \text { mòmí } & \text { yákò } & \text { lé! } \\ \text { ITRG } & \text { thus } & \text { CL6-chat } & \text { CONN } & \text { CL1.woman } & \text { POss:2SG } & \text { DEM }\end{array}$

'So, is this the conversation (speech) of your wife!?'

These prosodic features, the syllabic adaptation of words and the quantitative and qualitative adaptation of vowels, in particular in basilectal Bunia Swahili, result in a register which sounds very much like Central Sudanic languages in the area.

Bunia Swahili lects deviate from other Congo Swahili varieties not only in their segmental inventory and prosodic structure, but also in terms of a number of phonological processes. One characteristic and emblematic property of all varieties of Bunia Swahili is the omission of word-initial high front vowels (aphaeresis), which frequently occurs with the copula $(i) k o$ and the invariable demonstrative $(i) l e$.

Kutsch Lojenga (1994: 85-87) describes a similar phenomenon for the Central Sudanic language Ngiti, where " $[t]$ he vowel $\mathrm{I}$ in word-initial position must

TABLE 5 Deictic elements in ECs and Bunia Swahili

\begin{tabular}{|c|c|c|c|c|}
\hline (6) & $\begin{array}{l}\text { ECS } \\
i-k o \\
i-l e\end{array}$ & $\begin{array}{l}\text { Function } \\
\text { locative copula; CL9 } \\
\text { demonstrative; CL9 }\end{array}$ & $\begin{array}{l}\text { Bunia Swahili } \\
\text { ko } \\
\text { le }\end{array}$ & $\begin{array}{l}\text { Function } \\
\text { locative/existential copula } \\
\text { demonstrative (invariable) }\end{array}$ \\
\hline
\end{tabular}


be deleted in some well-defined contexts, and may be deleted in others ..." This applies for instance to the short forms of the $1^{\text {st }}$ and $2^{\text {nd }}$ singular and plural pronouns, changing Ima to $m a$ ( $1^{\text {st }}$ singular $)$ and ImyI to nyt $\left(2^{\text {nd }}\right.$ singular $)$ in Ngiti.

With other phonological processes in Bunia Swahili, it is not clear what their origin is. Vowel copying or complete assimilation occurs in certain forms, for example when the third person plural subject concord ( $w a$ - in Standard Swahili) forms a phonological word with the locative copula $=k o$, resulting in a form boko.

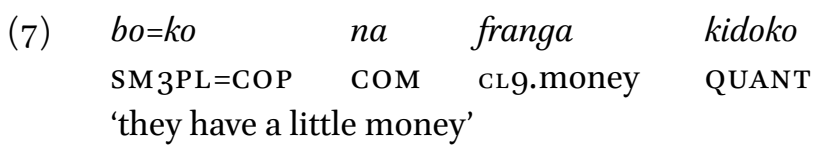

\subsection{Morphosyntactic Variation}

As with phonological variation, morphosyntactic realizations depend upon a speaker's chosen register. While acrolectal realizations usually reflect morphosyntactic features characteristic of Standard Swahili, a speaker's mesolectal or basilectal realization of Bunia Swahili is characterized by a high number of emblematic features from Central Sudanic languages. Examples in the next sections are predominantly from the basilectal and mesolectal varieties.

\subsubsection{Number Marking}

Plural marking in Bunia Swahili deviates considerably from Ecs due to the omission of morphologically marked plurals. Bunia Swahili nouns, other than those belonging to classes $1\left(m u^{-}\right)$and $2(b a-)$ as referents with the feature [+human], lack obligatory singular-plural pairing.

As shown in Table 6, the noun class system reveals some differences from ECS (as described in Polomé, 1967, among others) and from Congo Swahili regiolects. The most salient difference from Congo Swahili regiolects like Kivu Swahili concerns the number of prefixes, and also some singular/plural pairings. The Swahili spoken in the Kivu Provinces and also the variety from Katanga have morphologically marked diminutives/pejoratives, filling the slots of noun classes $12(\mathrm{ka}-)$ and $13(\mathrm{tu}-)$, a common classification among Bantuists. Bunia Swahili diminutives have to be expressed periphrastically with the help of adjectives such as kidoko 'small'. Another striking feature of Congo Swahili regiolects, which is absent in Bunia Swahili, is the differentiation between noun classes $11(u-)$ and $14(b u-)$. ECS, however, has lost this distinction between the two classes, as pointed out by Nurse \& Hinnebusch (1993: 552). Consequently, their occurrence in Western Swahili lects other than Bunia Swahili 
TABLE 6 The noun classes of Standard Swahili and acrolectal Bunia Swahili

\begin{tabular}{|c|c|c|c|}
\hline CL & Prefix & Example in Bunia Swahili & $\begin{array}{l}\text { Singular/plural pairing in Bunia } \\
\text { Swahili }\end{array}$ \\
\hline 1 & $m u-$ & mutoto 'child' & \\
\hline & $m w-$ & mwanamuke 'woman' & \\
\hline 2 & $b a-$ & $\begin{array}{l}\text { batoto 'children' } \\
\text { banabake 'women' }\end{array}$ & $\begin{array}{l}\text { also used in double plural } \\
\text { marking }\end{array}$ \\
\hline 3 & $m u-, m w-$ & mwaka 'year, years' & no morphological number \\
\hline 4 & $m i-$ & miaka 'year, years' & $\begin{array}{l}\text { marking, both classes express } \\
\text { singular and plural concepts }\end{array}$ \\
\hline 5 & - & shamba 'field, fields' & morphological plural marking is \\
\hline 6 & $m a-$ & $\begin{array}{l}\text { mashamba 'fields' } \\
\text { mafuta 'oil, petrol' }\end{array}$ & $\begin{array}{l}\text { necessary in cL6 only when } \\
\text { functioning as unspecified } \\
\text { quantifier ('some'), optionally } \\
\text { double-plural in cL6+CL2 }\end{array}$ \\
\hline 7 & $k i-$ & kiyana 'boy, boys' & $\begin{array}{l}\text { CL7 expresses both singular and } \\
\text { plural concepts }\end{array}$ \\
\hline 8 & $v i-$ & viyana 'boy, boys' & rarely used \\
\hline 9 & (i) $N$ & $\begin{array}{l}\text { imbwa 'dog, dogs' } \\
\text { njia 'way, ways' }\end{array}$ & $\begin{array}{l}\text { both CL9-1 o can express } \\
\text { singular and plural }\end{array}$ \\
\hline 10 & (i) $N$ & $\begin{array}{l}\text { imbwa 'dog, dogs' } \\
\text { njia 'way, ways' }\end{array}$ & \\
\hline 11 & $\begin{array}{l}u^{-} \\
l u^{-}\end{array}$ & $\begin{array}{l}\text { ukuta 'wall' } \\
\text { lulime 'language, tongue' }\end{array}$ & $\begin{array}{l}\text { most concepts in CL11 are } \\
\text { singularia tantum }\end{array}$ \\
\hline 14 & $u-$ & utoto 'childhood' & - \\
\hline 15 & $k u-$ & $\begin{array}{l}\text { kungiya 'to enter' } \\
\text { kunya 'to drink' }\end{array}$ & - \\
\hline
\end{tabular}

must be due to their reintroduction through borrowing from other Bantu languages (see Bose \& Nassenstein 2016 for Kivu Swahili). Their absence in Bunia strongly suggests that this variety of Western Swahili was introduced through a separate (northern rather than southern) route. There is morphological evidence for this hypothesis, such as the presence in noun class 11 of lexemes with the prefix $u$, as in ECS, and other class 11 nouns with the more archaic prefix $l u$-, as in other Congolese Swahili varieties, such as uzi 'string' but lu-pao 'shovel'. Phonological evidence (as noted in Section 3.1 above) for the two layers can be found in the presence of word-initial $h$-, only in acrolectal Bunia Swahili, 
and the occurrence of epenthetic consonants as in ku-sahabu ('to forget', from $k u$-sahau, whereby the prefix $k u$-is used as an infinitive marker), found in all other Congo Swahili varieties. Verbs such as ku-jaribu ('to try'), retained in Bunia Swahili, but replaced by ku-pima in all other Congo Swahili dialects, provide lexical evidence for the two historical layers, as does ku-nunua ('to buy'), again used in Bunia Swahili but replaced by $k u-u z a$ in other dialects. (The actual list of divergent lexemes is much longer.)

Due to this clear divergence from other Swahili varieties spoken in the Congo, we can assume a separate wave of diffusion of Swahili through Ituri, distinct from the spread that is well documented in the literature (as discussed in Goyvaerts \& Kabemba, 1986: 212-213, quoted above). These lexical and structural properties found in Bunia Swahili are not the result of replication from regional languages, but are due to the spreading of East African Swahili along a northern route. There is no historical evidence for Sudan Arabs using Swahili along this route but Swahili documents in Arabic script were found as far as the Uele region of the Belgian Congo by the end of the $19^{\text {th }}$ century (Luffin 2007). As pointed out by Luffin (ibid., p. 23) "it seems that all the Congolese Swahili documents were written in Kiunguja, the Swahili spoken in Zanzibar" (which forms the basis for today's ECS). Further, there is evidence for Swahili used as a contact language at the Alur court (Southall 2004) in neighboring British East Africa. Moreover, as stated by Luffin (p. 21), Swahili traders had already been in contact with Azande people from the broader region, which supports the hypothesis of a northern Swahili influx. The presence of various Swahili borrowings into Azande provides additional influence for this contact scenario (Helma Pasch, p.c.).

Czekanowski (1924: 242-245) discusses penetrations by Swahili-speaking Zanzibaris (so-called Wangwana) from the south into Ituri in his expedition report of the "Deutsche Zentral-Afrika-Expedition 1907-1908", and states that numerous Zanzibari settlements were established there, and that the language was adopted by local followers of the slave traders, often called Manyema, after the province of the same name in eastern Congo (Page 1974: 69).

However, the transport of gum and ivory along already existing trade routes across Uganda and from there on to Kenya was led by Sudan Arabs (ibid., p. 248). Meeuwis (2006) also differentiates between Zanzibari Arabs (Wangwana) and Sudan Arabs, who entered the Congo through today's South Sudan and Uganda. The Swahili variety which spread along these latter trade routes into Ituri was morphologically closer to ECS than the Zanzibari Arabs' variety, whose Swahili was closer to today's Kivu and Kisangani Swahili. These two historical layers would explain the mixture of Swahili features found in Bunia Swahili which cannot be explained through interference from regional Central Sudanic languages. 


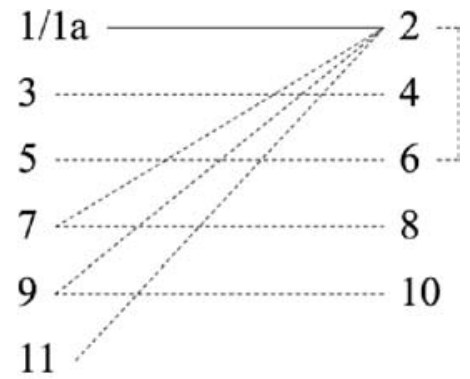

14

15
FIGURE 2

Obligatory and optional noun-class pairing

As illustrated in Figure 2, only class 1 nouns (such as mu-toto 'child') and class 1a nouns (for example baba 'father') reveal obligatory plural marking in class 2 (ba-toto, ba-baba) in Bunia Swahili (here expressed with a straight line); all other noun-class pairings are optional realizations (expressed with a dotted line). In other words, the pairs $3-4,5-6,7-8$ and $9-10$ do not have to differ morphologically in order to express singular or plural concepts since they all denote [-human] concepts. Shamba (class 5, 'field') can thus express singular or plural, and so does ma-shamba (class 6); ki-su (class 7, 'knife') can be used as a singular or plural noun (class 8 ). The figure moreover reveals that class 7 ( $k i$-tu 'thing'), class 9 (nyumba 'house') and also class 11 (lu-lime 'language') can optionally form their plural in the general plural class 2 (ba-kitu, ba-nyumba, ba-lulime), when a speaker intends to emphasize a plural meaning of a noun; this however is rare. There is also an optional double plural marking of class 6 concepts in class 2 (ba-ma-shamba '(whatever) fields'), especially in mesolectal Bunia Swahili.

By using either quantifiers or numerals (which can be seen as substitute or compensating strategies for number marking on nouns), the [-human] head noun may take a plural meaning. Thus, quantifiers in Bunia Swahili function as pluratives, as in examples (8-9). Numerals fulfill the same function, as becomes evident in (10).

$\begin{array}{llll}\text { jana } \quad m i=l i-u z a & k i-t u & \text { mingi } \\ \text { yesterday } \quad \text { SM1SG=PAST-buy } & \text { CL7-thing } & \text { QUANT } \\ \text { 'yesterday I bought many things' } & \end{array}$

(9) shamba yote ya village ko ya bwana le field(s) QUANT CONN village COP CONN CL1a.Sir DEM 'all village fields belong to that man' 


\begin{tabular}{|c|c|c|c|c|c|}
\hline meza & le & ko & na & $k i-t i$ & ine \\
\hline cL9.table & DEM & $\mathrm{COP}$ & $\mathrm{COM}$ & cL7-chair & NUM \\
\hline
\end{tabular}

This restructured number marking system, involving a reduction in the number of noun classes alternating between singular and plural forms, is characteristic of all Bunia Swahili lects. Initially, this may have been the result of pidginization (as also observed in Juba Arabic by Nakao to appear). But the presence of typologically identical patterns in neighboring Central Sudanic languages such as Lendu and Ngiti, would have reinforced this pattern of reduced number marking on nouns (see also Tucker \& Bryan, 1966: 39-40). Kutsch Lojenga in her grammar of Ngiti (1994: 133) observes:

Certain subcategories of nouns [...] are marked for number. These are the nouns denoting humans, and any compound form whose second part is in fact originally a [+human] noun [...]. There are three strategies for plural formation in the categories of nouns mentioned: suppletion, the use of Bantu-like prefixes mU- and pba-, and tone.

This system of number marking for nouns is common in Central Sudanic languages in the area, as illustrated in Table 7 .

\subsubsection{Cross-Reference Marking on the Verb}

The essential role played by Central Sudanic languages in the historical restructuring of all varieties of Bunia Swahili is particularly clear with respect to the pronominal reference system. Standard Swahili as spoken in Kenya or

TABLE 7 Optional plural suffixes in Central Sudanic languages

\begin{tabular}{|c|c|c|}
\hline Term & Gloss & Language \\
\hline$j k u ́(-y I)$ & 'woman; women' & $\begin{array}{l}\text { Lugbara; adapted from } \\
\text { Tucker \& Bryan (1966: 40) }\end{array}$ \\
\hline $\operatorname{ago}(I)$ & 'person(s)' & $\begin{array}{l}\text { Logo; adapted from Tucker } \\
(1940: 136)\end{array}$ \\
\hline toko $(I)$ & ‘woman; women’ & Logo; ibid. \\
\hline$n d r i(i)$ & 'goat(s)' & Logo; ibid. \\
\hline ílígó (pl. ilígò) & 'knife; knives' & Keliko; ibid. \\
\hline
\end{tabular}


TABLE 8 Subject proclitics in Bunia Swahili

\begin{tabular}{lll}
\hline & Singular & Plural \\
\hline 1 & $m i-$ & \\
2 & $w e^{-}$ & $n i-$ \\
3 & $y e-[+$ human $]$ & $b a-[+$ human $]$ \\
& $i-[-$ human $]$ & $i-[-$ human $]$ \\
\hline
\end{tabular}

TABLE 9 Independent object pronouns and object enclitics

\begin{tabular}{lll}
\hline & Singular & Plural \\
\hline 1 & miye & siye \\
2 & we $(y e)$ & niye \\
3 & ye $(y e)[+$ human $]$ & bao $[$ +human $]$ \\
& yao/-ao $[$-human $]$ & yao/-ao $[$-human $]$
\end{tabular}

Tanzania uses subject and object prefixes on the verb. All varieties of Bunia Swahili appear to use proclitic subject pronouns and enclitic object pronouns derived from the independent pronouns of Swahili, as shown in Tables 8-9.

Subject proclitics are a common feature of Central Sudanic languages; however, they are not typical of Congo Swahili regiolects other than Bunia Swahili. Instead, Swahili varieties such as Kisangani Swahili reveal systems of subject prefixes as part of the concordance system (parallel to ECS) rather than cliticized forms of the independent pronouns (Nassenstein, 2015: 78). Their proclitic nature in Bunia Swahili becomes clear whenever a noun or noun phrase serves as the subject of the sentence; there is no pronominal subject marker on the verb (contrary to ECS), as shown in examples (11) and (12); in the basilectal variety of Bunia Swahili these subject proclitics also alternate in terms of their ATR quality, depending on the vowel quality of the following verb root.

$\begin{array}{lll}\text { ba-toto } & \text { ta-rudiya } & \text { kesho } \\ \text { cL2-child } & \text { FUT-return } & \text { tomorrow } \\ \text { 'the children will return tomorrow' }\end{array}$


$\begin{array}{ll}\text { (12) bisi } & \text { pa-li-kuya } \\ \text { CL9.bus } & \text { NEG-PAST-come } \\ \text { 'the bus did not come' } & \end{array}$

Pronominal subject marking on verbs in Bunia Swahili constitutes a replication or calquing of patterns in Central Sudanic languages like Ngiti, where shortened forms of the independent pronouns occur as phonologically bound markers on the verb, which use exactly the same system, as shown in Table 10.

In the following example from Ngiti, adapted from Kutsch Lojenga (1994: 191), the short form of the independent $2^{\text {nd }}$ person pronoun $(\dot{t}) n y \dot{t}$ occurs as a proclitic (ny-) on the verb.

\section{(13) Ngiti \\ inzá ny-ikpè \\ NEG 2SG-cough:PF.PR \\ 'you have not coughed'}

ECS has pronominal object prefixes following the subject prefix and the tenseaspect prefix (if the latter occurs) and preceding the verb stem. The enclitic nature of object pronouns in Bunia Swahili becomes obvious when analyzing their coalescence with verb-final vowels. The independent pronoun yeye $\left(3^{\text {rd }}\right.$ person singular [+human]), for example, turns into an enclitic $=e$ (alternating

TABLE 10 Subject pronouns and clitics in Ngiti (Kutsch Lojenga 1994: 192)

\begin{tabular}{|c|c|c|}
\hline & $\mathrm{S} / \mathrm{O}$ pronouns & $\mathrm{S}$ \\
\hline $1 S G$ & $(\dot{t}) m a$ & $m^{-}$ \\
\hline $2 S G$ & $(\dot{t}) n y \dot{t}$ & $n y^{-}$ \\
\hline $3 S G$ & $k a, k a ̀$ & $k^{\prime}-$ \\
\hline 3SG.REFL/LOG & $n d \grave{t}$ & $n d^{\prime-}$ \\
\hline 1PL.EXCL & $(\grave{t}) m \check{a}$ & $m^{2}-$ \\
\hline $2 \mathrm{PL}$ & $(\dot{t}) n y \grave{t}$ & $n y^{2}-$ \\
\hline $3^{\mathrm{PL}}$ & abádhí & "- \\
\hline $3^{\text {PL.REFL/LOG }}$ & $\grave{t}$ & \\
\hline INDEF & $k a$ & $k^{-}$ \\
\hline 1PL.INCL & $\grave{a} l \grave{\varepsilon}$ & $(\grave{a}) l-$ \\
\hline
\end{tabular}


in terms of ATR harmony between $=\varepsilon$ and $=e$ in the basilectal variety) when coalescing with verb-final $-a$ (see 14a). When the final vowel $-a$ co-occurs with the $2^{\text {nd }}$ person singular object weye, this coalesces in $-o(14 \mathrm{~b})$. When - $a$ meets the [-human] object pronoun yao, the object enclitic is -ao (14c).

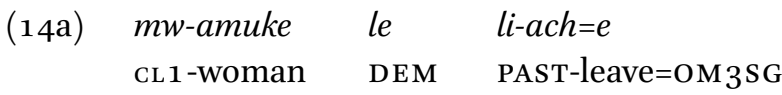
'the woman left him'
(14b) $\quad m i=p a-l i-o n=o$
SM $1 S$ G $=$ NEG - PAST - See $=$ OM 2 SG
'i did not see you'
(14c) $\quad b a=p a-z i-e l e z a=a o \quad$ bien
SM 3PL=NEG-HAB-explain=OM 3SG:INANIM good
'usually they do not explain it well'

In the Central Sudanic languages Lendu and Ngiti, pronominal objects always occur immediately after the verb, as shown in the following example from Ngiti, adapted from Kutsch Lojenga (1994: 197).
(15) Ngiti
kàla $\quad k a$
3sg.see:PF.PR $\quad 3$ SG:O
'(s)he has seen him/her'

Viewing this kind of transfer as replication from these two regional Central Sudanic languages also helps to explain the use of two types of third person pronouns as bound forms on verbs in dependent clauses in Bunia Swahili. The use of $y e$ - as against $a$-corresponds to a difference in Lendu and Ngiti between so-called anaphoric and logophoric reference. The prefix $a$ - (sG; $b a-\mathrm{PL})$ is used in order to refer back to a subject introduced in a preceding sentence or clause; see example (16a), adapted from Kutsch Lojenga (1994: 211), and example (16b) from Bunia Swahili.
kitdyò
dha ndilti
dìná
3SG.draw:PF.PR water 3 SG:LOG.place:PF.PR
head.3SG:LOG
'(s)he ${ }_{i}$ drew water, $\left(\right.$ she $\left._{i}\right)$ put it on her $\mathrm{r}_{i} /$ his $_{\mathrm{i}}$ head' 


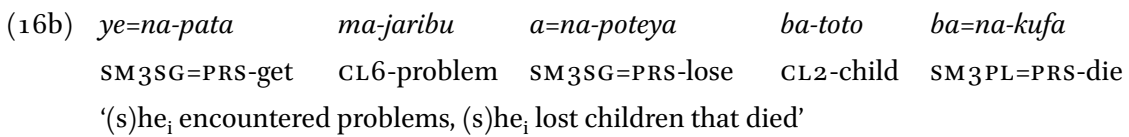

The following examples $(17 \mathrm{a}-17 \mathrm{~b})$ illustrate disjunctive reference in Ngiti (Kutsch Lojenga, 2007: 210) and the parallel structure in Bunia Swahili.

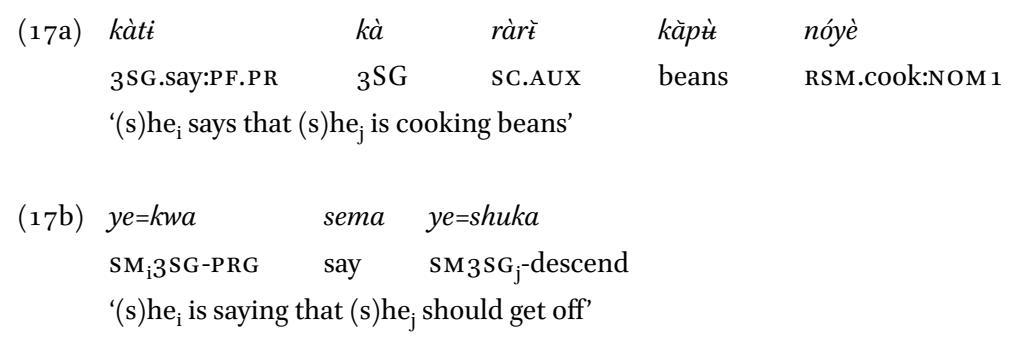

\subsubsection{Demonstratives}

Demonstratives in Bunia Swahili are invariable and usually follow the head noun. While Kivu Swahili, Lubumbashi Swahili and Kisangani Swahili all reveal complex systems of demonstrative determiners and pronominals, Bunia Swahili speakers make use of $(i) l e$ both as determiner and pronominal form (see 18-19) regardless of the noun it modifies, without making a distinction between proximal and distal reference. The initial weak vowel $i$ - is usually omitted when directly following a vowel. In order to specify the deictic perspective of the speaker toward the speech event, the locative adverbials (apa 'here'), pale 'there' and kule 'over there' are added to the invariable demonstrative.

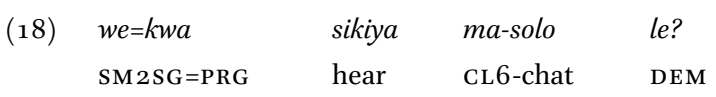

'Aren't you following this/that conversation?'

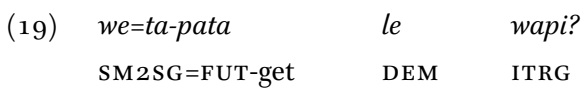

'Where will you get this/that one?'

This system in Bunia Swahili parallels the semantic system found in Central Sudanic languages like Ngiti, which distinguishes between closeness to the speaker, e.g. yà 'this (sG)', closeness to the hearer or at an intermediate distance, e.g. wj̀ 'that (sG)', and far away from both speaker and hearer, e.g. ndă 
'that over there (SG)' (Kutsch Lojenga, 1994: 372-373). These normally precede the head noun in Ngiti (ibid., p. 371).

In Bunia Swahili, the standard form (i)le constitutes the unmarked choice and does not necessarily have to be specified by adding apa 'here' in order to express proximity. However, both (i)le pale and (i)le kule need the adverbial in order to express distance ('that one over here' vs. 'that one over there/that one that was mentioned'). The $3^{\text {rd }}$ person singular pronoun ye forms a phonological word with the demonstrative, yele. This latter form functions as an independent subject pronoun in such constructions.

\begin{tabular}{|c|c|c|c|c|c|c|}
\hline (20) & {$[\ldots]$} & njo & ye-le & uliza & njo & miye \\
\hline & & FOC & $\mathrm{SM}_{3} S \mathrm{SG}-\mathrm{DEM}$ & ask & FOC & OMISG \\
\hline
\end{tabular}

Interestingly, the combination of $y e$ and $l e[j \varepsilon l \varepsilon]$ is reminiscent of a Lendu suffix $-\ell \varepsilon$, which according to Tucker \& Bryan (1966: 36$)$ "is probably the word for 'person' or 'being'” (as in $6 a-l \varepsilon$ 'Lendu person'), and which is also used as a prefix for body part nomenclature. Possibly, this homophonous Lendu suffix $-l \varepsilon$ contributed to the creation of a form yele in Bunia Swahili. Such cases of grammatical accommodation are known from other contact situations. Ameka (2009), for example, shows that in the Togo Mountain language Likpe the verb $l \varepsilon$ ' hold' is used to express a present progressive meaning, parallel to the use of le 'be at' for present tense in Ewe, which is an important contact language for many speakers of Likpe.

Demonstratives that are deliberately placed before the head noun are usually structurally oriented towards an acrolectal Kivu or Standard Swahili speech style. In ECs the position of the demonstrative -le relative to the noun is also variable (whereby it functions like the definite article in English when preceding the noun, according to Ashton 1944: 59); other $h$ - demonstratives (huyu, huyo etc.) expressing proximity usually follow the head noun.

(21) Mesolectal Bunia Swahili

$\begin{array}{llllllll}\text { wakati } & y a & \text { ile } & \text { ma-isha } & \text { yake } & y a & k u \text {-kuwa } & \text { journaliste } \\ \text { time } & \text { CONN } & \text { DEM } & \text { CL6-life } & \text { POSS3SG } & \text { CONN } & \text { INF-be } & \text { CL1a.journalist }\end{array}$
'during this time when he was a journalist...'

(22a) ECS (adapted from Ashton 1944: 59)

yule $\quad m$-tu

CL1.DEM CL1-man

'the man (away from speaker)' 
(22b) Ecs (adapted from Ashton 1944: 59)

$m$-tu yule

CL1-man CL1.DEM

'that man'

\subsubsection{The Construction of Reflexives}

While Ecs expresses reflexives through the use of a prefixed reflexive marker $-j i-$, which occupies the object concord slot (or the slot for pronominal objects), other Swahili varieties reveal deviating strategies. Kivu Swahili follows the ECS system, whereas Kisangani Swahili often makes use of the French reflexive -se- (with an allomorph -s'-), in co-occurrence with an increased number of borrowed French verb stems (see Nassenstein, 2015). Bunia Swahili speakers mark reflexivity by using the reciprocal derivational suffix -an(example 24).

(23) Ma'di (Blackings \& Fabb 2003: 92)

$\bar{\jmath}-n d r \bar{\varepsilon} \quad r \bar{\delta} \quad k \hat{\imath} \quad a d z i n \bar{t}$

3-see REFL PL yesterday

'they saw each other yesterday'

(24) Bunia Swahili

$b a=n a-z i-p e n d-a n a$

sana

SM3PL=PRS-HAB-love-REFL/REC very

'they love each other a lot'

'they love themselves a lot'

The appropriate form of peke ('self, alone') can be added in order to show that a reflexive reading is intended.

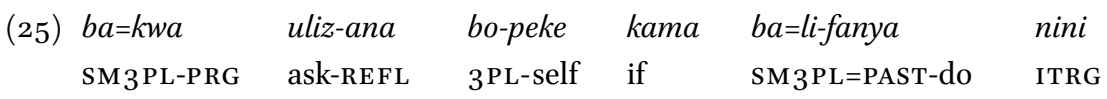
'they asked themselves what they did wrong'

This is again significant, as numerous Central Sudanic languages also reveal patterns of a morphological reciprocal-reflexive that serves both functions and often carries a grammaticalized meaning of 'body', for instance Ma'di (see Blackings \& Fabb, 2003: 92-93). In Ngiti, reflexivity is expressed differently, reflexive markers being identical with personal pronouns in most cases (see Kutsch Lojenga, 1994: 199). 


\subsubsection{Negation Marking}

Negation in Bunia Swahili can also be considered to be an emblematic feature of which speakers are aware; its high recognition factor is often prone to mimicry by non-speakers in metadiscourse, for example when referring to Bunia Swahili as a mi-pana-jua (lit. 'me-not-know') Swahili or the mi-pana-mi-pana ('me-not-me-not') variety, and thus considering it a greatly simplified kind of Swahili.

Instead of a set of negative subject concords as found in ECs (see Ashton, 1944) and affirmative-negative tense and aspect equivalents (-li- vs. -ku-; -navs. $-i$ ), Bunia Swahili uses one main invariable negation marker $p a-$, which follows the subject proclitic (examples 26-27) and precedes tense and aspect prefixes.
$m i=p a-z i-p e n d a$
ma-kelele
SM 1 SG =NEG-HAB-like
CL6-noise

'i do not like noise'

(27) mu-toto

pa-zi-sikiya

CL1-child

NEG-HAB-hear

'the child does not listen'

Apart from the invariable negative marker $p a$-, there exists a negative form -wezi, which is often used when modal verbs occur (examples 28-29).
(28) $\quad m i=w e z i$
SM1SG-NEG:MOD
pasha lala na we=kwa
be.able.to sleep and SM2SG=PRG
nguruma
'i cannot sleep while you are snoring'
(29) $y e=w e z i$
kufa njala
SM 3 SG =NEG :MOD
die hunger

'(s)he cannot die of hunger'

A third invariable negative element is bado, which expresses a negated completive aspect.
(30) ye
bado
fika
3SG
NEG:COMPL
arrive
'(s)he has not yet arrived' 
In the Central Sudanic languages in the area, Lendu and Ngiti, negation marking is slightly more complex, and also differs from Bunia Swahili in terms of its morphosyntactic realization. Here, the negation markers can take one of two different positions in the sentence (Kutsch Lojenga, 1994: 242): in initial position (NEG S VO) or immediately following the conjugated verb (S V NEG O). If an auxiliary occurs, the negative marker either occurs in initial position (NEG $\mathrm{S}$ AUX O V) or immediately following the auxiliary verb (S AUX NEG O V). In this respect, constituent order in Bunia Swahili differs from that in Lendu or Ngiti negative clauses.

Negative imperatives reveal stronger similarities with Ngiti (and Lendu) forms. Instead of using a negative mood prefix -si- as in Standard Swahili (and other Congo Swahili varieties), Bunia Swahili makes use of the negative marker $p a$-followed by the present tense prefix - na- and the verb stem (see 31). Kutsch Lojenga (1994: 256) states for Ngiti that "the negative imperative is formed with the negative marker inzit preceding the imperative verb form", which thus reveals structural similarities to Bunia Swahili.

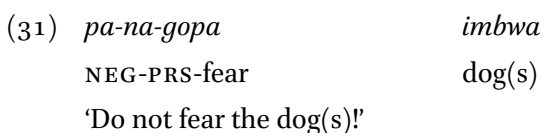

\subsubsection{Syntactic Variation}

A further interesting replication of the structure of the Central Sudanic languages Ngiti and Lendu is found in the division between different types of nonverbal predications. ECS differentiates between predicative constructions expressing an identity (' $\mathrm{X}$ is $\mathrm{Y}^{\prime}$ ) or attribute (i.e. adjectival forms) on the one hand and locative or existential constructions on the other. While the first type requires a copula $n i$ for all persons (see $32 \mathrm{a}-\mathrm{b}$ ), locative constructions require an inflected form of $-k o$ (as in 33).

\begin{tabular}{|c|c|c|c|}
\hline \multirow[t]{3}{*}{$(32 a)$} & yeye & $n i$ & $m$-ganga \\
\hline & $3 \mathrm{SG}$ & $\mathrm{COP}$ & CL1-doctor \\
\hline & \multicolumn{3}{|c|}{ '(s)he is a traditional doctor' } \\
\hline \multirow[t]{3}{*}{$(32 b)$} & yeye & $n i$ & $m$-refu \\
\hline & $3 \mathrm{SG}$ & $\mathrm{COP}$ & CL1-tall \\
\hline & '(s)he & & \\
\hline \multirow[t]{2}{*}{ (33) } & yeye & $y u-k o$ & nyumba-ni \\
\hline & $3 \mathrm{SG}$ & SM 3 SG-LOC & CL9.home-LOC \\
\hline
\end{tabular}


But in all varieties of Bunia Swahili non-verbal predications are treated on a par (contrasting with verbal constructions) in that they all require the locative copula ko.

$\begin{array}{llll}\text { ECS } & & & \\ \text { (34a) jina } & \text { yangu } & k o & \text { Fabrice } \\ \text { CL9.name } & \text { POSS1SG } & \text { COP } & \text { F. }\end{array}$

'my name is Fabrice'

(34b)fasi ku vile ko fasi kwenye ba=neza tuma miye CL9.place LOC town COP CL9.place REL:LOC SM3PL=can send OMISG 'the place in town is the place they can send me to'

This parallels the basic distinction between non-verbal and verbal predications in the Central Sudanic language Ngiti; the following examples are from Kutsch Lojenga (1994: 276-281):

Ngiti (Kutsch-Lojenga 1994: 276)

(35a) ka ní mùngangà

3SG RM doctor

'(s)he is a doctor'

(ibid., p. 279)

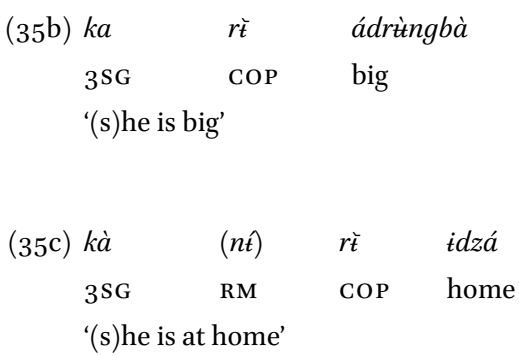

The brief comparison between Bunia Swahili and regional languages like Ngiti above shows that various structures in the former constitute replications from the latter. Nevertheless, structural differences remain, in particular where the typological disparity between this Bantu language and regional Central Sudanic languages cannot be overcome without major syntactic restructuring, for example with respect to relative clauses. In Bunia Swahili, the invariable relative clause marker is nye (example 36 ), serving for both [+human] and [-human] referents in subject and object relative clauses, which follow the head noun. The relative clause marker is -enye in other Congo Swahili regiolects, 
where it also requires noun class agreement. However, while the relative clause marker in Lendu and Ngiti is also invariable, the relative clause itself precedes the head noun. In the following subject relative clause from Lendu (with ná as a relative clause marker) the high tone marking imperfective aspect forms a

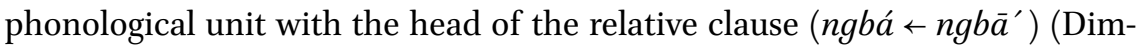
mendaal et al., 2019: 356 .

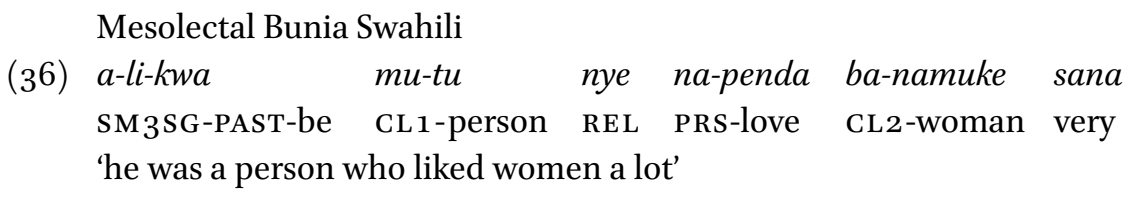

Lendu

(37)

$\begin{array}{llllll}{\left[\begin{array}{lll}n g b a ́ & d z \check{l} & n a ́\end{array}\right]} & t s \grave{z} t s \bar{z} & k \bar{a} & n z a ́ \\ \text { child.IPF } & \text { buy:PRES } & \text { REL } & \text { bananas } & \text { ripen:PF } & \text { NEG } \\ \text { 'the bananas which the child is buying are not ripe' }\end{array}$

While armed conflict (in particular the "Ituri War" between 1999 and 2003, referred to in Section 2 above) over the past decades appear to have resulted in an elaboration of Bunia Swahili registers and their association with different ethnic identities, they have also strengthened this variety of Swahili as an interethnic and supra-regional language, which in its current post-conflict setting symbolizes stability and a unifying regional identity despite the presence of several registers.

The more acrolectal registers are often used among university students, in offices of the province capital, or among (Hema) Muslims who acquired ECS in Koran schools (in the DRC or Uganda), thereby also emphasizing educational values. Speakers who have spent time in the Kivu Provinces, where the more prestigious Kivu Swahili is spoken, also tend to produce an acrolectal realization of Bunia Swahili, which is very close to the Kivu regiolect. Parallel structures include a preference for Kivu or ECs subject prefixes (for example $1^{\text {st }}$ person plural $t u$-instead of the more basilectal proclitic $s i=)$, the use of Kivu noun class pairings, and ECS negation marking patterns.

The basilectal register, on the other hand, may be used when the setting and relationships among speakers are clearly defined, especially in order to emphasize a common local or in particular a rural identity. The emblematicity 
of such a 'Lendu/Ngiti way of speaking' is based on the common historical roots of their speakers and their arrival in the area before the Hema.

Because basilectal Bunia Swahili is less prestigious, speakers often tended to shift to the more prestigious acrolectal register during the initial stages of the fieldwork on which this contribution is based, especially when recording of conversations was involved. In the course of the fieldwork sessions, the same speakers who had first produced a more acrolectal variety tended to employ more and more meso- and basilectal forms of Bunia Swahili. Changing the register towards acrolectal Bunia Swahili also avoids mockery and stigmatization. Kivu Swahili or Kisangani Swahili speakers, for example, often ridicule speakers of basilectal Bunia, claiming that the latter sounds "un peu comme quand les nigérians parlent anglais" [a bit like when Nigerians speak English]. Their label 'mi-pana-mi-pana Swahili (lit. me-not-me-not Swahili) apparently reminds them of a simplified or "tarzanized" speech. Moreover, a shift towards the acrolectal register precludes the ascription of a particular ethnic label to a speaker, which is also of prime importance in a post-conflict setting such as Ituri.

The mesolectal register reveals core features of ECS as well as of Central Sudanic languages, and is often used by speakers who would use basilectal or acrolectal registers in other settings. When a Lendu or Ngiti speaker who frequently uses a more basilectal register intends to realize a more acrolectal pattern, this will most likely lead to a 'mesolectal' realization of Bunia Swahili. The same applies to a speaker more commonly using the acrolectal register of Bunia Swahili, when (s)he finds him/herself in a conversation where a more basilectal realization is favorable, for example when wishing to express a regional Ituri identity (in contrast to a Kivu identity, for instance). The mesolectal variety consequently involves a fluid pool of choices which is not clearly determinable in terms of its phonological or morphosyntactic features, embodying features from Ecs and Kivu Swahili, but also Central Sudanic elements.

Similar observations on the emblematic use of different registers, often by one and the same speaker, are made by Nakao (to appear) on Juba Arabic, a variety of Sudanese Arabic spoken in South Sudan with three variational parameters: basilect versus mesolect, urban versus rural, and modern versus archaic (or younger generations versus elder generations). University students from Juba, for example, may use either the basilectal variety (which has tone as a prosodic feature, in contrast with the acrolectal variety of Juba Arabic) or the mesolectal variety. 
Superficially, the basilectal variety of Bunia Swahili looks like morphologically simplified ("pidginized") Swahili, particularly because of its greatly reduced morphology. On closer inspection, however, it turns out that this variety shows strong structural convergence towards the regional Central Sudanic languages Lendu and Ngiti, which, like most other Central Sudanic languages, are characterized by a limited degree of affixational morphology.

This raises the question of the extent to which "pidgins" and "creoles" are the result of unique language contact processes, a position defended by many creolists in the past (e.g. Bakker 2008). Authors like DeGraff (2001) and Dimmendaal (2011: $235^{-236}$, ad passim), on the other hand, have emphasized the non-uniqueness of such languages, thereby arguing against their "exceptional" status in terms of their structure or genetic affiliation. In a recent volume on the typology and genetic affiliation of creole languages, edited by Bakker et al. (2017), an epilogue by Migge (2017:390) concludes that "there are no linguistic properties that are unique to creole languages", and that "creole grammars are not inherently simpler than those of other languages". The present study supports these claims.

Similar to basilectal Bunia Swahili, other Bantu languages in the area have adopted typological features from Central Sudanic languages as well. Kutsch Lojenga (2003) shows that in Kibila, for example, the "classical" 7-vowel Bantu system has been replaced by a 9-vowel system with ATR harmony, and that it has a petrified noun class system in which only animate nouns have separate singular and plural forms, whereas inanimate nouns only have one form used for both singular and plural. There is no historical evidence for pidginization as a basis for the morphological reduction in this Bantu language. The difference between this case and Bunia Swahili is the absence of additional registers (involving more versus less elaborate morphologies) in Kibila.

A further example of replication from Central Sudanic languages can be found in Bangala, a Bantu language spoken north of Bunia in the Democratic Republic of the Congo and extending into South Sudan and northwestern parts of Uganda. Bangala has repeatedly been claimed to be a pidgin (for example by Boone \& Watson, 1996: A7). However, it reveals similar Central Sudanic influences, for example in the restrictive use of plural marking nouns (see example $38 \mathrm{a}){ }^{2}$

2 Note also that Bangala distinguishes between 7 vowels, although in example 36 only 5 vowels are written, in line with the orthographic convention used for (Kinshasa) Lingala. 


$$
\begin{aligned}
& \text { Bangala (authors' fieldnotes) } \\
& \text { (38a) biróko, ba-biróko, nyónso azi } \\
& \text { thing(s) CL2-thing } \quad \text { QUANT COP } \\
& \text { 'thing(s), or things, all is there (meaning: can be said)' }
\end{aligned}
$$

$\begin{array}{llllll}\text { (38b) kulá } & \text { yangú } & \text { a-pis-í } & \text { ngai } & \text { ku-síka } & \text { té } \\ \text { thing } & \text { DEM } & \text { FV-give-ANT } & \text { OM1SG } & \text { CL15-happiness } & \text { NEG } \\ \text { 'this specific (one) thing did not make me happy' } & \end{array}$

While the distinction in number marking is productive in the Bantu language and lingua franca Lingala, it has been lost in Bangala. For example, bi-róko [bıróks], realized as bi-lóko in Lingala, denotes a morphological plural form of noun class 8 ('things'; originally with the singular e-lóko).

The term bi-róko can therefore represent both singular and plural concepts ('thing/s, stuff') in Bangala. When a plural connotation is intended, bi-róko can take the noun class 2 prefix $b a$ - (see example $38 \mathrm{a}$ ). When a specific singulative form is required, the lexeme kulá ('good, bad, special thing; affair') is used. This parallels the situation in the neighboring Central Sudanic languages (see Tucker \& Bryan, 1966: 39-40 and Table 7), where number is often not morphologically expressed, or is expressed only through optional suffixes, as in Logo, for example, whose speakers also tend to speak Bangala (Boone \& Watson 1996).

These examples show that restructuring in Bantu languages of this broader contact area, especially involving morphological simplification, is the result of calquing or replication from neighboring Central Sudanic languages rather than of "autogenetic" pidginization processes.

\section{Acknowledgments}

We are greatly indebted to Fabrice Emeritus Lopanto, Patrick Dhepana, Mohamed Kano, Nathalie, Didi Angaika, Kisembo and Germain for their time and support as language consultants between 2013 and 2015, as well as for their deep insights and explanations concerning Bunia Swahili. Henning Tamm is warmly thanked for connecting us with some of the speakers. This first overview paper is based on a larger corpus of elicited sentences and 34 free texts, as well as on qualitative sociolinguistic interviews with various interlocutors. We are indebted to the anonymous reviewers as well as the editor of the present journal for the exceptionally detailed comments and suggestions. We 
also gratefully acknowledge the help of Monika Feinen, who compiled the overview map of Congo Swahili dialects. Mary Chambers is warmly thanked for polishing up our English.

\section{List of Abbreviations}

$\begin{array}{ll}\text { CL } & \text { noun class } \\ \text { COM } & \text { comitative } \\ \text { COMP } & \text { complementizer } \\ \text { CONN } & \text { connective } \\ \text { COP } & \text { copula } \\ \text { DEM } & \text { demonstrative } \\ \text { ECS } & \text { East Coast Swahili/Standard Swahili } \\ \text { FOC } & \text { focus } \\ \text { FUT } & \text { future tense } \\ \text { HAB } & \text { habitual } \\ \text { INAN } & \text { inanimate } \\ \text { IND } & \text { indicative } \\ \text { ITRG } & \text { interrogative } \\ \text { LOG } & \text { logophoric } \\ \text { MOD } & \text { modality } \\ \text { NEG } & \text { negation } \\ \text { NOM } & \text { nominalized verb stem } \\ \text { NUM } & \text { numeral } \\ \text { OM } & \text { object marker } \\ \text { PAST } & \text { past tense } \\ \text { PF } & \text { perfective } \\ \text { PF.PR } & \text { perfective present } \\ \text { PL } & \text { plural } \\ \text { PLUP } & \text { pluperfect } \\ \text { POSS } & \text { possessive } \\ \text { QUANT } & \text { quantifier } \\ \text { RECP } & \text { reciprocal } \\ \text { REFL } & \text { reflexive } \\ \text { RSM } & \text { resumptive marker } \\ \text { SG } & \text { singular } \\ \text { SM } & \text { subject marker } \\ \text { SU } & \text { subject } \\ & \end{array}$




\section{References}

Ameka, Felix K. 2009. Likpe. In Gerrit J. Dimmendaal (ed.), Coding Participant Marking: Construction Types in Twelve African Languages, 239-279. Amsterdam and Philadelphia:John Benjamins.

Anonymous. 1975. Kingwana and Other Simplified Forms, Oceanic Linguistics Special Publications 14, A Bibliography of Pidgin and Creole Languages, 676-69o. University of Hawai'i Press.

Ashton, Ethel O. 1944. Swahili Grammar (Including Intonation). London: Longmans, Green \& Co.

Bakker, Peter. 2008. Pidgins versus creoles and pidgincreoles. In Kouwenberg and Singler (eds.), 130-157.

Bakker, Peter, Finn Borchsenius, Carsten Levisen and Eeva Sippola (eds.) 2017. Creole Studies - Phylogenetic Approaches. Amsterdam and Philadelphia: John Benjamins.

Blackings, Mairi and Nigel Fabb. 2003. A Grammar of Ma'di. Berlin: Mouton de Gruyter.

Boone, Douglas and Richard L. Watson. 1996. Moru - Ma'di Survey Report. Nairobi: Summer Institute of Linguistics.

Czekanowski, Jan. 1924. Wissenschaftliche Ergebnisse der deutschen ZentralAfrika-Expedition 1907-1908. Band IV, Zweiter Teil. Forschungen im Nil-KongoZwischengebiet. Leipzig: Klinkhardt \& Biermann.

DeGraff, Michel F. 2001. Language Creation and Language Change. Creolization Diachrony and Development. Cambridge, MA: The MIT Press.

Dimmendaal, Gerrit J. 2011. Historical Linguistics and the Comparative Study of African Languages. Amsterdam and Philadelphia: John Benjamins.

Dimmendaal, Gerrit J., Colleen Ahland, Angelika Jakobi and Constance Kutsch Lojenga. 2019. Linguistic features and typologies in languages commonly referred to as 'Nilo-Saharan'. In Ekkehard Wolff (ed.), The Cambridge Handbook of African Linguistics, 326-381. Cambridge: Cambridge University Press.

Goyvaerts, Didier and A. Kabemba. 1986. Le contexte historique de la naissance et de la diffusion du kingwana. In Didier Goyvaerts (ed.), Language and History in Central Africa. Antwerp Papers in Linguistics 44: 197-254.

Fabian, Johannes. 1986. Language and Colonial Power. The Appropriation of Swahili in the Former Belgian Congo 1880-1938. Cambridge: Cambridge University Press.

Fahey, Dan. 2013. Ituri. Gold, Land, and Ethnicity in North-Eastern Congo. London/Nairobi: Rift Valley Institute/Usalama Project.

Harries, Lyndon. 1955. Swahili in the Belgian Congo, Tanganyika Notes and Records 39: 12-15.

Heine, Bernd. 1973. Pidginsprachen im Bantubereich. Berlin: Dietrich Reimer Verlag. 
Kapanga, André Mwamba. 1993. Shaba Swahili and the processes of linguistic contact. In Francis Byrne \& John Holm (eds.), Atlantic meets Pacific. A Global View of Pidginization and Creolization, 441-458. Amsterdam and Philadelphia: John Benjamins.

Kouwenberg, Sylvia and John Victor Singler (eds.) 2008. The Handbook of Pidgin and Creole Studies. Oxford: Wiley-Blackwell.

Kutsch Lojenga, Constance. 1994. Ngiti: A Central-Sudanic Language of Zaire. Cologne: Rüdiger Köppe.

Kutsch Lojenga, Constance. 2003. Bila (D32). In Derek Nurse and Gérard Philippson (eds.), The Bantu Languages, 450-474. London and New York: Routledge.

Kutsch Lojenga, Constance. 2007. Coreference in Ngiti. In Mechthild Reh \& Doris L. Payne (eds.), Advances in Nilo-Saharan Linguistics, 143-161. Cologne: Rüdiger Köppe. Kutsch Lojenga, Constance. 2009. Kilungunya. A newly discovered and endangered secret Bantu language spoken in D.R. Congo. Paper presented at WOCAL 6, Cologne August 2009.

Luffin, Xavier. 2007. On the Swahili documents in Arabic script from the Congo (19 century). Swahili Forum 14: 17-26.

Maho, Jouni Filip. 2009. Nugl online. The online version of the New Updated Guthrie List, a referential classification of the Bantu languages. [http://www.goto.glocalnet .net/mahopapers/nuglonline. pdf] (accessed 13 March 2018).

Meeuwis, Michael. 1999. The White Fathers and Luganda: To the origins of French missionary linguistics in the Lake Victoria region. Annales Aequatoria 20: 413-444.

Meeuwis, Michael. 2006. The Lingala-Swahili border in north-eastern Congo: its origins in Belgian colonial state formation in the late nineteenth and early twentieth centuries. Africana Linguistica 12: 113-135.

Migge, Bettina. 2017. Epilogue: Of theories, typologies and empirical data. In Bakker et al. (eds.), Creole Studies - Phylogenetic Approaches, 389-394. Amsterdam and Philadelphia: John Benjamins.

Möhlig, Wilhelm J.G. 1995. Swahili Dialekte. In Möhlig and Miehe (eds.), 41-62.

Möhlig, Wilhelm J.G. and Gudrun Miehe (eds.). 1995. Swahili Handbuch. Cologne: Rüdiger Köppe.

Mpiranya, Fidèle. 2015. Swahili Grammar and Workbook. New York: Routledge.

Nakao, Shuichiro. To appear. A Grammar of Juba Arabic. ms.

Nassenstein, Nico. 2015. Kisangani Swahili: Choices and Variation in a Multilingual Urban Space. Munich: LINCOM.

Nassenstein, Nico. 2017. Pluractional marking in Bunia Swahili (Ituri Kingwana). Language Typology and Universals (STUF) 70(1): 195-213.

Nassenstein, Nico and Andrea Hollington (eds.). 2015. Youth Languages in Africa and Beyond. Berlin: de Gruyter Mouton.

Nassenstein, Nico and Paulin Baraka Bose. 2016. Kivu Swahili Texts and Grammar Notes. Munich: LINCOM. 
Nurse, Derek and Thomas J. Hinnebusch. 1993. Swahili and Sabaki: A Linguistic History. Berkeley and Los Angeles: University of California Press.

Page, Melvin E. 1974. The Manyema hordes of Tippu Tip: A case study in social stratification and the slave trade in Eastern Africa. The International Journal of African Historical Studies 7(1): 69-84.

Polomé, Edgar C. 1967. Swahili Language Handbook. Washington: Center for Applied Linguistics.

Pottier, Johan. 2009. Representations of ethnicity in the search for peace: Ituri, Democratic Republic of Congo. African Affairs 109(434): 23-50.

Reuster-Jahn, Uta, and Roland Kießling. 2006. Lugha ya Mitaani in Tanzania: The poetics and sociology of a young urban style of speaking with a dictionary comprising 1100 words and phrases. Swahili Forum 13 Special Issue.

Southall, Aidan W. 2004. Alur Society: A Study in Processes and Types of Domination. Reprint of the 1956 edition. Münster: LIT.

Tucker, A. N. 1940. The Eastern Sudanic Languages, Volume 1. London: Oxford University Press.

Tucker, A. N. and Bryan, M. A. 1966. Linguistic Analyses: The Non-Bantu Languages of North-Eastern Africa. London: Oxford University Press.

Vorbichler, Anton. 1979. Sprachkontakte am Beispiel einiger Sprachen und Dialekte in Nordost-Zaire. Anthropos 74(3/4): 433-442. 